\title{
Bank Risk, Profitability, dan Investment Diversification: Studi Perusahaan Perbankan di Indonesia
}

\author{
Aditya Kurnia Indrajaya ${ }^{1}$, Stevan Goklas Simanjuntak ${ }^{2}$, dan Susy Muchtar ${ }^{3}$ \\ ${ }^{1,2,3}$ Faculty of Economics and Business, Trisakti University Jakarta \\ Email Address: \\ adityakurnia69@gmail.com; stevangoklas@gmail.com; ;usy_muchtar@trisakti.ac.id
}

\begin{abstract}
The aims of this study was to determine whether risk assessment, company profits, and macroeconomic factors affect the decisions of banking companies in determining investment diversification. The independent variables in this study are credit risk, liquidity risk, profitability, inflation rate, and gross domestic product (GDP) while the dependent variable is investment diversification. There are three control variables in this study, namely bank size, interbank ratio, LA, and capitalization ratio. This study was conducted using a data sample of 41 banking companies listed on the Indonesia Stock Exchange (IDX) within a reporting period of 5 years (2016 - 2020) and using panel data regression model testing. The results of this study indicate that liquidation risk and credit have a negative effect, while the inflation rate and GDP have a positive effect on investment diversification. The results of this study can help bank financial management to manage investment diversification strategies by paying attention to risk and maximizing profitability. In the novelty of this study, the coefficient of variation is used to measure the dependent variable so that the measurement can be distinguished from other studies.
\end{abstract}

Keyword:Banking industry, Investment Diversification, Banking risk, Profitability, Inflation rate, Gross Domestic Product.

\begin{abstract}
Abstrak: Penelitian ini dilakukan untuk menentukan apakah penilaian risiko, profit perusahaan, dan faktor ekonomi makro mempengaruhi keputusan perusahaan perbankan dalam menentukan diversifikasi investasi. Variabel independen dalam penelitian ini ialah risiko kredit, risiko likuiditas, profitabilitas, tingkat inflasi, dan penerimaan domestik bruto (PDB) sedangkan variabel dependennya adalah diversifikasi investasi. Adapun tiga variabel kontrol dalam penelitian ini, yaitu ukuran bank, rasio antar bank, la, dan rasio kapitalisasi. Studi ini dilakukan menggunakan sampel data 41 perusahaan perbankan yang terdaftar di Bursa Efek Indonesia (BEI) dalam kurun waktu pelaporan selama 5 tahun (2016 - 2020) dan menggunakan pengujian model regresi data panel. Hasil dari penelitian ini menunjukkan risiko likuidasi dan kredit berpengaruh negatif sedangkan tingkat inflasi dan PDB berpengaruh positif terhadap diversifikasi investasi. Hasil penelitian ini dapat membantu manajemen keuangan perbankan untuk mengelola strategi diversifikasi investasi dengan memperhatikan risiko dan memaksimalkan profitabilitas. Dalam keterbaruan studi ini, koefisien variasi digunakan untuk mengukur variabel dependen agar pengukuran bisa dibedakan dari penelitian lain.
\end{abstract}


Kata Kunci: Industri perbankan, diversifikasi investasi, risiko perbankan, profitabilitas, tingkat inflasi, penerimaan domestic bruto (PDB).

\section{PENDAHULUAN}

Sektor perbankan telah mengalami perkembangan yang sangat pesat di kawasan Timur Tengah dan Afrika Utara baik bank Syariah maupun bank konvensional (Uslu, 2020). Sejak tahun 2008, krisis global sangat mempengaruhi sektor perbankan konvensional dan Syariah di Kawasan MENA. Namun, bank Syariah justru berhasil menunjukkan kinerja keuangan yang baik selama terjadinya krisis (Cihakl dan Hesse, 2011) dan berperan besar dalam perekonomian negara dan global dengan total aset sebesar US\$ 3,1 triliun pada 2011 (Bankscope).Reformasi besar pada sektor perbankan di kawasan MENA yang dipimpin oleh otoritas publik dengan tujuan untuk merestrukturisasi bank umum dan memperkuat pengawasan perbankan dengan memperkenalkan kedua prinsip kehati-hatian perundang-undangan dan sistem manajemen risiko (Mkadmi et al, 2020). Dalam era pandemi Covid-19, sektor perbankan di Kawasan MENA mengalami tekanan dan menyebabkan pertumbuhan ekonomi menjadi lambat, adanya penurunan harga aset dan volume perdagangan, menyusutnya neraca perbankan dan sektor riil, serta meningkatnya proporsi utang negara. Namun sektor perbankan mampu mengatasi krisis karena latar belakang sejarahnya yang kuat dan sejumlah intervensi yang didukung dari pemerintah pusat (Avci dan Nassar, 2017).

Awal mula munculnya ekonomi syariah di Indonesia diawali dengan beroperasinya Bank Muamalat pada 1 Mei 1992. Pada Januari 2020 tercatat ada 14 bank syariah dan 20 UUS yang beroperasi di wilayah Indonesia (BPS, 2020). Berdasarkan Laporan Profil Industri Perbankan (OJK, 2020), pada Triwulan IV tahun 2020 kinerja Bank Umum Syariah (BUS) dan UUS (Unit Usaha Syariah) masih tergolong cukup stabil. Tahun 2021, merger tiga bank syariah BUMN dianggap sebagai langkah awal yang bagus untuk memperluas jangkuan pasar dan akses likuiditas kepada bank induknya, namun kompetisi antar bank syariah masih lemah untuk mendukung akselerasi industri dan akhirnya menuntut bank syariah memperbesar kapasitasnya untuk bergerak dengan bank konvesional.

Saat ini, industri perbankan konvensional di Indonesia tengah menghadapi risiko yang samakin rumit sebab aktivitas bisnis bank yang beragam dan berkembang pesat sehingga bank diharuskan untuk mengelola risiko. Pengelolaan risiko tersebut harus sejalan dengan standar global yang ditetapkan oleh Bank for International Settlements (BIS) dengan konsep permodalan baru dimana kerangka perhitungan permodalan lebih sensitif terhadap risiko (risk-sensitive). Terutama di tengah pandemi Covid-19 rasio NPL bank konvensional di Indonesia cenderung meningkat dari tahun 2020.

Keuntungan bank konvensional dapat diukur dari selisih antara pembayaran bunga kepada deposan atau beban bunga dengan pendapatan bunga kredit kepada debitur. Selain itu, bank mendapatkan keuntungan dari biaya administrasi termasuk biaya administrasi bulanan, transaksi antar bank, dan biaya pembuatan kartu ATM. Bank Syariah tidak menerapkan bunga dalam aktivitas transaksi, sehingga keuntungan bank Syariah bergantung pada pendapatan tetap (kontrak komersial), pembayaran royalty, dan bagi hasil (Gafrej dan Boujelbene, 2021). Dalam perbankan Syariah, penggunaan kontrak 
kemitraan atau profit sharing meningkatkan risiko kredit di mana risiko tersebut terkait dengan moral hazard dan asymmetric information (Gafrej dan Boujelbene, 2021).

Kemampuan bank konvensional dan bank Syariah dapat dianalisis dari bagaimana bank tersebut dapat meminimalisir risko kredit dan risiko likuiditas. Risiko kredit dapat menyebabkan bank default. Sejak tahun 2008, risiko ini menyebabkan krisis keuangan global (Lopez et al., 2014). Menurut (Imbierowicz dan Rauch, 2014) dan (Houque et al., 2015) terdapat dua faktor yang menyebabkan risiko kredit, yaitu faktor mikroekonomi seperti likuiditas bank, modal bank, bank size, pesaing bank, credit derivative, corporate governance, serta moral debitur dan faktor makroekonomi dapat dilihat pada inflasi, pengangguran, tarif bunga, siklus kredit dan bisnis serta harga properti. Maka dari itu, analisis faktor makroekonomi sangat penting bagi pembuat kebijakan untuk mencegah terjadinya krisis keuangan (Canh et al., 2021). Di lain sisi kontrak konvensional mengajukan dana untuk membayar kredit yang diajukan. Kerugian akibat credit risk dapat ditunjukkan melalui besaran rasio Non-Performing Loan (NPL) untuk bank konvensional dan Non-Performing Financing (NPF) untuk bank syariah (Pradana Reza, 2018).

Menurut data Badan Pusat Statistik (BPS), rasio NPL bank konvensional di Indonesia menunjukkan rata-rata sebesar $3,25 \%$ sedangkan data dari Otoritas Jasa Keuangan (OJK), kredit perbankan konvensional pada Juni 2021 mengalami peningkatan sejumlah Rp67,39 triliun dan telah tumbuh sejumlah 0,59\% (yoy) atau 1,83\% (ytd) menjadi Rp5.581,8 triliun. Hal ini disebabkan adanya stimulus dari pemerintah sehingga menunjukkan peningkatan tren kredit yang disalurkan selama empat bulan. Peningkatan kredit ini merupakan hasil akibat desakan atas mulai membaiknya permintaan kredit seiring dengan pulihnya kinerja dan aktivitas korporasi, rumah tangga, dan UMKM.

Merujuk pada penjabaran latar belakang di atas dan penelitian terdahulu yang telah dilakukan oleh (Gafrej dan Boujelbene, 2021) di MENA tahun 2021 menunjukkan bahwa adanya pengaruh credit risk, liquidity risk, dan profitability terhadap investment diversification. Sehingga penelitian ini akan meneliti topik yang sama dengan ruang lingkup Indonesia. Oleh karena itu, penelitian ini akan berjudul "Bank Risk, Profitability, dan Investment Diversification: Studi Perusahaan Perbankan di Indonesia".

\section{KAJIAN TEORI}

Perusahaan yang melakukan investasi pasti akan mengharapkan pengembalian di masa yang akan datang. Selain itu, perusahaan juga akan melaksanakan beberapa strategi investai guna meminimalisir risiko, yaitu dengan melakukan diversifikasi investasi. Diverisifikasi portfolio atau investasi adalah strategi investasi yang diakui secara luas yang bertujuan untuk mengurangi varians total dari pengembalian investasi yang diharapkan ( $\mathrm{Yu}$ dan Kim, 2021). Perusahaan perbankan biasanya mengalokasikan investasi di beberapa industri guna menimalisir risiko. Namun demikian, antara industri satu dengan industri lain harus memiliki pengaruh negatif. Karena apabila suatu industri mengalami penurunan nilai, maka masih terdapat industri lain yang masih mengalami pertumbuhan nilai (cateris paribus). Dengan demikian, strategi investasi ini dapat membuat perusahaan lebih aman secara finansial di tengah ketidakpastian.

Dalam penelitian (Gafrej dan Boujelbene, 2021) investment diversification dapat diukur menggunakan Non-Interest Income (NONII) dan Herfindahl-Hirschmann Index 
(HHI). NONII digunakan oleh beberapa penelitian terdahulu untuk mengukur investment diversification bank dengan mempertimbangkan faktor risiko dan kinerja perbankan. Jika hasil perhitungan NONII tinggi, maka strategi diversifikasi bank dinilai berhasil. Sebaliknya, jika hasil perhitungan NONII rendah maka bank belum memiliki kemampuan untuk melakukan diversifikasi pada investasinya. NONII dapat dihitung dengan membagi Non-Interest Income dengan Net Operating Income. Sedangkan, HHI merupakan pengukuran untuk mengetahui proksi diversifikasi dan konsentrasi kegiatan operasional bank. (Karkowska, 2019) telah membuktikan bahwa pengaruh bank risk terhadap investment diversification dengan menggunakan pengukuran HHI. Berbeda dengan NONII, HHI menunjukkan bahwa bank akan mengurangi ketergantungannya pada interest income sehingga bank memiliki peluang untuk mencari sumber pendapat lain. Untuk mengukur pendapatan bank dan investment diversification, penelitian sebelumnya menggunakan Herfindahl Hirshmaan Index (HHI). Dalam hal ini, variabel kinerja mengguanakan rasio keuangan seperti Return on Asset (ROA) dan Return on Equity (Alkhouri dan Arouri, 2021).

Investment Diversification pada bank bertujuan untuk mengurangi eksposur liquidity risk dengan cara meminimalkan konsentrasi sumber (deposit) dan mengalokasi deposit dan non-deposit dana untuk berbagi jenis investasi di tingkat lokal atau internasional (Jahn et al., 2013). Invesment Diversification bertujuan untuk mengurangi potensi kerugian dan meningkatkan nilai pada keputusan investasi yang dilakukan. Teori Portofolio Modern yang dikembangkan oleh Markowitz berguna dalam pengembangan Investment Diversification. Teori ini menunjukkan dalam konteks pengembalian aset tidak sempurna berkorelasi, maka diversifikasi mengarah pada peningkatan nilai perusahaan dan pengurangan risiko. Selain itu, (Chen et al., 2013) menyarankan bahwa bank harus melakukan diverisifkasi kreditnya untuk meminimalisir risko seperti yang dipersyaratkan oleh teori portfolio. (Alandejani et al., 2017) menyarankan supaya bank Syariah di Kawasan MENA harus fokus pada Investment Diversification pada sektor riil sehingga dapat mengurangi risiko kredit. Dalam hal ini credit risk berpengaruh siginifikan terhadap Investment Diversification.

Menurut (Saunders dan Cornett, 2011) mendefinisikan credit risk sebagai risiko ketika adanya arus kas yang berasal dari pinjaman serta surat berharga yang dimiliki oleh lembaga keuangan kemungkinan tidak dibayarkan secara penuh. Penyaringan dan pengendalian credit risk dan meningkatkan kualitas pinjaman merupakan mata rantai utama dari manajemen risiko bank (Wang Rui dan Luo Hang, 2020). Dalam penelitian Rupeika-Apoga, (Zaidi, dan Thalassinos, 2018) menyatakan bahwa tingginya eksposur jumlah kredit yang bermasalah mencerminkan tingginya tingkat kredit macet atau NPL. Kredit macet (NPL) bisa disebabkan karena terlalu banyak proyek pemerintah atau swasta yang bermasalah dibiayai melalui pinjaman dari bank (Ghenimi et al., 2020). Risiko bank yang tidak dapat diminimalisir tidak hanya mengurangi profitabilitas bank tetapi juga menyebabkan menjadi default atau bangkrut. Penelitian (Nguyen, 2019), (Ammar dan Boughrara, 2019), (Gafrej dan Boujelbene, 2021) mengindikasikan bila semakin kian tinggi rasio NPL maka akan menurunkan tingkat HHI.

Berdasarkan penelitian (Ghenimi et al., 2020), (Hacini Ishaq et al., 2021), (Hugonnier dan Morellec, 2017) liquidity risk merupakan rasio yang krusial karena dapat memicu bank menjadi default atau bangkrut terutama jika bank tidak mampu untuk memberikan dana kepada deposan disaat mereka membutuhkan.Menurut penelitian 
(Marozva, 2020) ketika kondisi ekonomi dalam keadaan tertekan, strategi diversifikasi investasi yang kurang tepat pada sisi aset dan sisi kewajiban dalam neraca bank dapat menyebabkan adanya risiko likuiditas. Hasil dari penelitian (Karkowska, 2019), (Gafrej dan Boujelbene, 2021), dan (Nguyen, 2019) menyimpulkanliquidity risk berpengaruh negatif terhadap NONII. Profitability merupakan sebuah rasio yang menggambarkan kemampuan perusahaan dalam memperoleh laba dari aktivitas bisnisnya pada kondisi normal (Henry, 2015). Penelitian (Kipleting, 2016), (Nguyen, 2019), (Alkhouri dan Arouri, 2021) dan (Ammar et al., 2019) menunjukkan bahwa kinerja bank berpengaruh secara positif dan signifikan terhadap investment diversification.

Gross Domestic Bruto (GDP) atau Produk Domestik Bruto (PDB) memuat siklus bisnis ekonomi suatu negara, investasi dan perkembangan ekonomi suatu negara amat ditentukan oleh fungsi likuiditas dan kinerja perbankan. Pertumbuhan PDB suatu negara juga mengukur pertumbuhan investasi bank. Jika sebuah bank memiliki peluang investasi yang baik, maka mereka dapat menggunakan arus kasnya dalam proyek-proyek yang sehat dan memiliki nilai positif. Hal ini akan mengarah pada peningkatan kinerja bank dan mengurangi risiko kebangkrutan (Alkhouri dan Arouri, 2021). Penelitian tersebut menyimpulkan bahwa peningkatan angka pertumbuhan PDB suatu negara maka selaras dengan peningkatan nilai investasi pada sektor perbankan sehingga kedua variabel tersebut berpengaruh secara positif. Namun demikian, masih ada bank yang memiliki cash flow yang tinggi tetapi tidak mampu mengelola proporsi investasinya sehingga akan memiliki nilai investasi yang negatif. Penelitian tersebut menyimpulkan bahwa semakin tinggi tingkat pertumbuhan PDB suatu negara maka akan kian tinggi pula nilai investasi pada sektor perbankan sehingga kedua variabel tersebut berpengaruh secara positif. Berdasarkan penelitian (Amidu dan Wolfe, 2013) menunjukkan bahwa faktor makroekonomi khususnya tingkat PDB berpengaruh negatif terhadap HerfindahlHirschmann Index (HHI). Hal ini sesuai dengan hasil penelitian (Gafrej dan Boujelbene, 2021) mengemukakan bahwasanya tingkat pertumbuhan PDB tidak berpengaruh signifikan terhadap NONII dan HHI.

Bank size secara teoritis menggunakan natural logarithm dari total aset sebagai representasi berdasarkan penelitian dari (Koju et al., 2018). Semakin banyak aset yang bank miliki akan kian meningkatkan ukuran bank tersebut. Bank size mencerminkan skala bank melalui total aset dan kepemilikan modalnya. (Büyükşalvarci, 2012) berpendapat bahwa bank size merupakan faktor penting karena sangat erat kaitannya dengan kepemilikan bank dan akses permodalannya mencerminkan kepentingan bank dalam menghindari risiko kebangkrutan (default) atau risiko manajerial. Berdasarkan penelitian (Nguyen, 2019), bank size berpengaruh positif terhadap investment diversification. Semakin besar ukuran simpanan bank, maka akan semakin tinggi saldo pinjaman bagi pelanggan. Dalam penelitian tersebut, bank size diukur menggunakan natural logarithm dari total assets. (Curi et al., 2015) berpendapat bahwa ada hubungan non-linear antara bank size dengan kinerja bisnis.

Interbank Ratio (IBR) merupakan rasio yang menunjukkan perbandingan dana yang dipinjamkan sebuah bank kepada bank lain dengan jumlah dana yang dipinjam oleh bank itu sendiri. Jika bank memiliki nilai lebih dari 100 pada rasio ini, maka bank memiliki kemampuan likuiditas yang baik karena dinilai mampu memberikan pinjaman ke bank lain daripada meminjam dana di pasar (Megeid, 2016). (Ekpu dan Paloni, 2015) menjelaskan bahwa Interbank Ratio (aset antar bank terhadap kewajiban antar bank) 
mengukur nilai pinjaman kepada bank lain atau simpanan yang ditempatkan pada bank lain. Dalam penilitian ini loan to deposit ratio digunakan untuk merepresentasi interbank ratio pada sebuah bank. loan to deposit ratio yang tinggi mencerminkan tingginya kontribusi pinjaman pada keuangan bank dan bank mungkin tidak mampu menutupi kebutuhan dana yang tidak terduga (Meng et al., 2017). (Rengasamy, 2014) berpendapat bahwa loan to deposit ratio yang lebih tinggi meningkatkan risiko likuiditas dan sekaligus menurunkan risiko operasional yang diukur dengan profitabilitas bank.

Proses pembentukan modal sangat penting untuk industri perbankan terlepas dari sifat bank. Modal yang lebih besar berarti bank akan menghadapi lebih sedikit masalah atau situasi berisiko (Ghenimi dan Chaibi, 2020). Permodalan yang kuat pada bank menunjukkan bahwa bank mampu memenuhi simpanan permintaan dan menrepresentasikan kepada nasabah bank tentang stabilitas dan kemampuannya untuk melindungi simpanan mereka terutama pada saat periode ketidakpastian seperti krisis keuangan (Ghosh, 2016). Penelitian tentang bagaimana meningkatkan permodalan bank sudah dilakukan terhadap banyak pasar keuangan di Afrika sebagai usaha untuk meningkatkan ketahanan bank (Tahir, Adegbite, dan Guney, 2017). Dalam penelitian ini, capitalization ratio diukur menggunakan Capital to asset ratio (CAP) dengan menghitung rasio capital terhadap total asset. Bank dengan rasio modal terhadap aset (Capital to asset ratio) yang lebih tinggi dianggap relatif lebih aman dan memiliki risiko yang lebih kecil dibandingkan dengan lembaga dengan rasio modal yang lebih rendah (Dietrich dan Wanzenried, 2011). (Dietrich dan Wanzenried, 2011) juga menjelaskan bahwa bank yang memiliki modal lebih tinggi dinilai lebih aman dan tetap mampu menghasilkan keuntungan bahkan saat ekonomi sulit.

\section{Hipotesis}

Hipotesis yang peneliti gunakan dalam penelitian ini antara lain:

$\mathrm{H}_{1}$ : Credit risk berpengaruh negatif terhadap investment diversification

$\mathrm{H}_{2}$ : Liquidity risk berpengaruh negative terhadap investment diversification

$\mathrm{H}_{3}$ : Profitability berpengaruh positif terhadap investment diversification

$\mathrm{H}_{4}$ : Inflasi berpengaruh negatif terhadap investment diversification

$\mathrm{H}_{5}$ : GDP berpengaruh positif terhadap investment diversification

$\mathrm{H}_{6}$ : Bank size berpengaruh positif terhadap investment diversification

$\mathrm{H}_{7}$ : Interbank ratio berpengaruh negatif terhadap investment diversification

$\mathrm{H}_{8}$ : Capitalization ratio berpengaruh positif terhadap investment diversification 


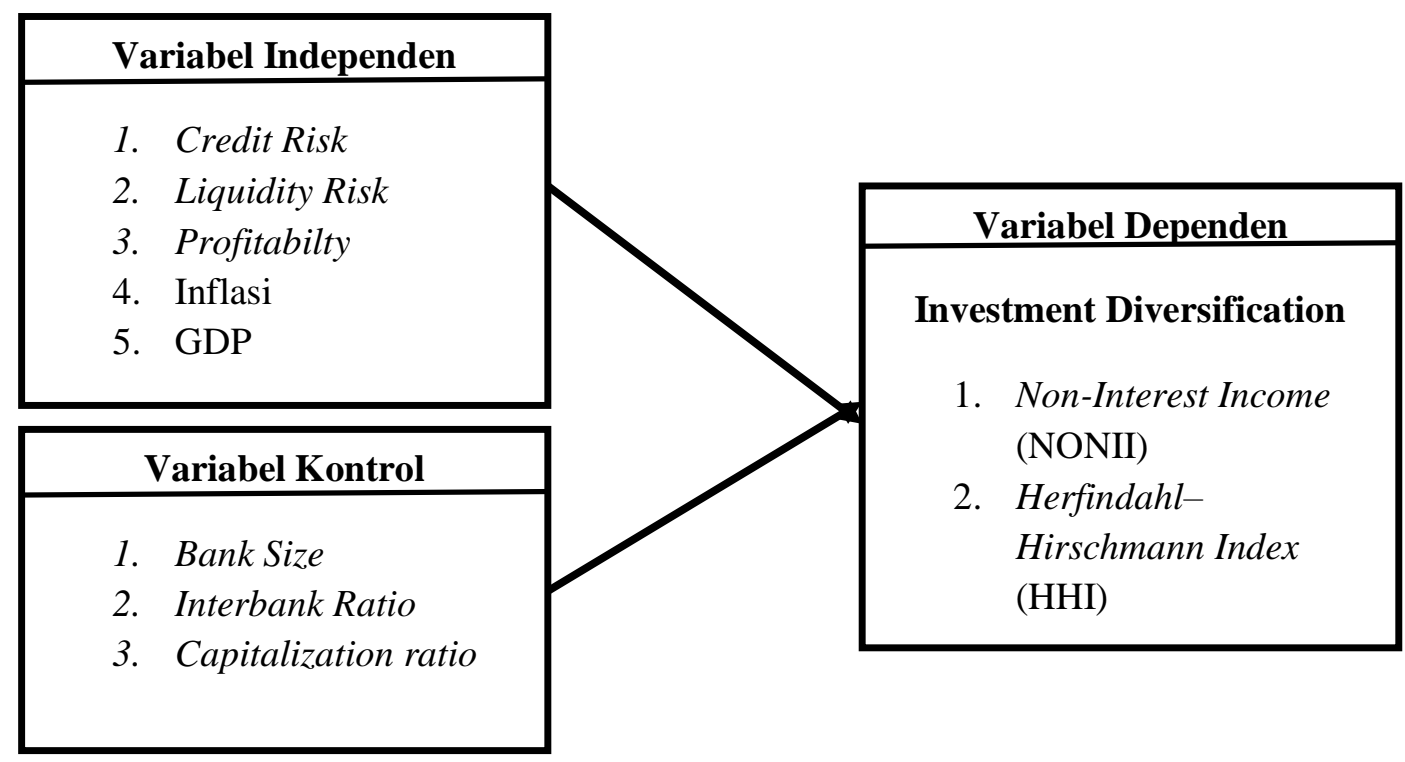

Gambar 1. Model Penelitian

\section{METODOLOGI}

Penelitian ini mengaplikasikan pendekatan kuantitatif melalui analisis statistik yang digunakan untuk menguji hipotesis pengaruh antaraliquidity risk, credit risk, profitability, inflation rate, dan Gross Domestic Product sebagai variabel independen terhadap investment diversification sebagai variabel dependen. Penelitian ini juga melaksanakan uji atas hipotesis bank size, interbank ratio, dan capitalization ratio sebagaivariabel kontrol yang dikendalikan untuk menjaga hubungan antara varibel dependen dan independen.

Populasi yang digunakan dalam penelitian yakni perusahaan perbankan yang tercatat di BEI (Bursa Efek Indonesia). Data sampel berupa rasio keuangan dari laporan keuangan populasi selama periode 2016-2020 dan diambil dari website www.idx.com atau website bank terkait. Untuk menentukan sampel teknik pengambilan sampel purposive sampling dilakukan dengan menggunakan kriteria tertentu, dimana sampel yang diambil memiliki pengaruh yang besar dalam hal relevansi dan kedalaman (Apostolopoulos dan Liargovas, 2016). Batasan yang digunakan (1) Perusahaan perbankan konvensional dan syariah yang terdaftar secara konsisten selama periode 2016-2020, (2) Tidak mengalami delisting selama periode 2016-2020, dan (3) Memiliki laporan keuangan yang detail dan selaras dengan kebutuhan data variabel yang akan digunakan pada penelitian. Data penelitian yang diperoleh dari hasil teknik purposive sampling sebanyak 200 observasi. 
Tabel 1. Pengukuran Variabel

\begin{tabular}{|c|c|c|c|c|}
\hline $\begin{array}{c}\text { Jenis } \\
\text { Variabel }\end{array}$ & Nama Variabel & Simbol & Pengukuran & Referensi \\
\hline \multirow[b]{2}{*}{$\begin{array}{l}\text { Variabel } \\
\text { Dependen }\end{array}$} & $\begin{array}{l}\text { Non-Financing } \\
\text { Income }\end{array}$ & NONII & $\frac{\text { Net Interest Income }}{\text { Total Onerating }}$ & \multirow[b]{2}{*}{$\begin{array}{c}\text { (Gafrej dan } \\
\text { Boujelbene, } \\
\text { 2021) }\end{array}$} \\
\hline & $\begin{array}{l}\text { The Herfindahl- } \\
\text { Hirschmann Index }\end{array}$ & HHI & {$\left[\frac{\text { Non Interest Income }}{\text { Net Operating Income }}\right]^{2}+\left[\frac{\text { Net Interest Income }}{\text { Net Operating Income }}\right]^{2}$} & \\
\hline \multirow{5}{*}{$\begin{array}{l}\text { Variabel } \\
\text { Independen }\end{array}$} & Credit Risk & NPL & $\frac{\text { Total Bad loans }}{\text { Total loans }}$ & $\begin{array}{l}\text { (Nguyen, } \\
\text { 2019) }\end{array}$ \\
\hline & Liquidity Risk & LTA & $\frac{\text { Net loan }}{\text { Total assets }}$ & \multirow{7}{*}{$\begin{array}{c}\text { (Gafrej dan } \\
\text { Boujelbene, } \\
\text { 2021) }\end{array}$} \\
\hline & Profitability & ROA & $\frac{\text { Net income }}{\text { Total Asset }}$ & \\
\hline & Inflasi Rate & INF & Annual percentage rate of inflation & \\
\hline & $G D P$ & GDP & Growth rate of GDP in percentage & \\
\hline \multirow{3}{*}{$\begin{array}{l}\text { Variabel } \\
\text { Kontrol }\end{array}$} & Bank Size & SIZE & Natural logarithm of total assets & \\
\hline & Interbank Ratio & IBR & Loans due from banks to deposits due to banks & \\
\hline & $\begin{array}{l}\text { Capitalization } \\
\text { Ratio }\end{array}$ & CAP & Capital to total assets ratio & \\
\hline
\end{tabular}

\section{HASIL PENELITIAN DAN PEMBAHASAN}

Uji Chow. Tujuan pengujian ini untuk memutuskan model terbaik untuk penelitian ini, yaitu antara fixed effect atau common effect. Hipotesis pengujian yang digunakan adalah:

$\mathrm{H}_{0}$ : Model yang lebih tepat yaitu common effect.

$\mathrm{H}_{\mathrm{a}}$ : Model yang lebih tepat yaitu fixed effect.

Jika probabilitas chi-square memberikan hasil $<5 \%$, maka $\mathrm{H}_{0}$ tidak diterima dan $\mathrm{H}_{\mathrm{a}}$ diterima. Sehingga kesimpulannya yang didapatkan pada penelitin ini menggunakanfixed effect. Berikut hasil pengujian yang dilakukan (Tabel 2):

Tabel 2.Hasil Uji Chow

\begin{tabular}{c|c|c|c}
\hline Dependent & Chi-Square & Probability & Keputusan \\
\hline HHI & 138.725301 & 0.0000 & $\mathrm{H}_{0}$ ditolak, Fixed Effect Model yang dipilih \\
\hline
\end{tabular}
Sumber: Output Panel Data RegresiEviews 12.0

Uji Hausman. Tujuan pengujian ini untuk menentukan model yang terbaik untuk penelitian, yaitu antara random effect atau fixed effect. Hipotesis pengujian yang digunakan adalah:

$\mathrm{H}_{0}$ : Model yang lebih tepat yaitu random effect. 
$\mathrm{H}_{\mathrm{a}}$ : Model yang lebih tepat yaitu fixed effect.

Jika probabilitas chi-square menghasilkan nilai > 5\%, maka $\mathrm{H}_{0}$ diterima dan $\mathrm{H}_{\mathrm{a}}$ ditolak. Sehingga kesimpulan penelitin yang dilakukan yaitu menggunakan random effect. Berikut hasil pengujian (Tabel 3):

Tabel 3.Hasil Uji Hausman

\begin{tabular}{c|c|c|c}
\hline Dependent & Chi-Square & Probability & Keputusan \\
\hline HHI & 8.562947 & 0.0380 & $\mathrm{H}_{0}$ diterima, Random Effect Model yang dipilih \\
\hline
\end{tabular}

Sumber: Output Panel Data RegresiEviews 12.0

Uji F. Mengacu pada hasil uji model, diketahui bila probabilitas $F$-statistic menunjukkan nilai sebesar $0.000000<0.05$. Berdasarkan hasil uji tesebut maka dapat ditunjukkan bahwa variabel independen yaitu credit risk, liquidity risk, profitability, inflation rate, dan GDP berpengaruh kepada variabel dependen yaitu investment diversification, maka dari itu dapat ditarik kesimpulan jika model regresi layak digunakan dalam penelitian.

Uji Goodness of Fit (Adjusted $\boldsymbol{R}^{2}$ ). Berdasarkan hasil perhitungan Uji Goodness of Fit (Adjusted $\mathrm{R}^{2}$ ), hasil menunjukkan bahwa nilai adjusted $R^{2}$ sebesar 0.631460 . Artinya, variabel independent seperti credit risk, liquidity risk, profitability, inflation rate, dan GDP dan variabel kontrol bank size, interbank ratio, capitalization ratio dapat menjabarkan variasi dari variabel dependen, yakni The Herfindahl-Hirschmann Index (HHI) sebesar $63.15 \%$. Sisanya, 36.85\% menjelaskan bahwa HHI dipengaruhi oleh variabel-variabel lain yang tidak terdapat dalam model ini.

Model Regresi. Mengacu pada penelitian sebelumnya (Gafrej dan Boujelbene, 2021), penelitian ini menerapkan analisis regresi data panel dengan persamaan regresi sebagai berikut:

Model 1: Model pada perusahaan perbankan konvensional

$$
\begin{aligned}
& H H I_{i t}=\alpha_{0}+\beta_{1} L T A_{i t}+\beta_{2} N P L_{i t}+\beta_{3} R O A_{i t}+\beta_{4} C A P_{i t}+\beta_{5} I B R_{i t}+ \\
& \beta_{6} S I Z E_{i t}+\beta_{7} G D P_{i t}+\beta_{8} I N F_{i t}+e_{i t}
\end{aligned}
$$

Model 2: Model pada perusahaan perbankan syariah

$$
\begin{aligned}
& N_{N O N I}=\alpha_{0}+\gamma_{1} L T A_{i t}+\gamma_{2} N P F_{i t}+\gamma_{3} R O A_{i t}+\gamma_{4} C A P_{i t}+\gamma_{5} I B R_{i t}+ \\
& \gamma_{6} S I Z E_{i t}+\gamma_{7} G D P_{i t}+\gamma_{8} I N F_{i t}+e_{i t} \ldots
\end{aligned}
$$

Keterangan:

$$
\begin{array}{ll}
\mathrm{HHI}_{i t} & =\text { Invesment diversification (Bank Konvensional) } \\
\mathrm{NONNI}_{i t} & =\text { Invesment diversification (Bank Syariah) } \\
\mathrm{LTA}_{i t} & =\text { Liquidity risk } \\
\mathrm{NPL}_{\mathrm{it}} & =\text { Credit risk(Bank Konvensional) } \\
\mathrm{NPF}_{i t} & =\text { Credit risk (Bank Syariah) } \\
\mathrm{ROA}_{i t} & =\text { Profitability }
\end{array}
$$




\begin{tabular}{|c|c|}
\hline $\mathrm{CAP}_{\mathrm{it}}$ & $=$ Capitalization ratio \\
\hline $\mathrm{IBR}_{\mathrm{it}}$ & $=$ Interbank ratio \\
\hline $\mathrm{SIZE}_{\mathrm{it}}$ & $=$ Bank size \\
\hline $\mathrm{GDP}_{\text {it }}$ & $=$ Gross domestic product \\
\hline $\mathrm{INF}_{\mathrm{it}}$ & $=$ Inflation rate \\
\hline
\end{tabular}

Tabel 4. Hasil Analisis Statistik Deskriptif Bank Konvensional

\begin{tabular}{c|c|c|c|c|c}
\hline Variabel & Observation & Minimum & Maksimum & Mean & Std Dev \\
\hline NPL & 184 & 0.000 & 0.158 & 0.035 & 0.023 \\
\hline LTA & 184 & 0.191 & 0.812 & 0.604 & 0.099 \\
\hline ROA & 184 & -0.117 & 0.045 & 0.004 & 0.020 \\
\hline INF & 184 & 0.017 & 0.036 & 0.028 & 0.006 \\
\hline GDP & 184 & -0.021 & 0.052 & 0.036 & 0.029 \\
\hline SIZE & 184 & 13.407 & 21.137 & 17.401 & 1.874 \\
\hline IBR & 184 & 0.390 & 2.109 & 0.882 & 0.215 \\
\hline CAP & 184 & 0.085 & 1.483 & 0.232 & 0.145 \\
\hline HHI & 184 & 0.500 & 1.631 & 0.708 & 0.148 \\
\hline
\end{tabular}

Sumber: Output Panel Data RegresiEviews 12.0

Tabel 5. Hasil Analisis Statistik Deskriptif Bank Syariah

\begin{tabular}{c|c|c|c|c|c}
\hline Variabel & Observation & Minimum & Maksimum & Mean & Std Dev \\
\hline NPL & 15 & 0.014 & 0.067 & 0.035 & 0.018 \\
\hline LTA & 15 & 0.000 & 0.707 & 0.297 & 0.279 \\
\hline ROA & 15 & -4.537 & 0.098 & -0.271 & 1.181 \\
\hline INF & 15 & 0.017 & 0.036 & 0.028 & 0.007 \\
\hline GDP & 15 & -0.021 & 0.052 & 0.036 & 0.030 \\
\hline SIZE & 15 & 12.202 & 17.871 & 16.102 & 1.692 \\
\hline IBR & 15 & 0.000 & 15.797 & 3.081 & 5.384 \\
\hline CAP & 15 & 0.115 & 0.494 & 0.269 & 0.109 \\
\hline NONII & 15 & 2.370 & 37.179 & 12.642 & 10.453 \\
\hline SuI
\end{tabular}

Sumber: Output Panel Data RegresiEviews 12.0

The Herfindahl-Hirschmann Index (HHI) menghasilkan nilai rata-rata sebesar 0.708 dengan nilai standar deviasi sebesar 0.148. Sedangkan Non-Financing Income (NONII) menghasilkan nilai rata-rata sebesar 12.642 dengan nilai standar deviasi sebesar 10.453. merujuk pada data tersebut, dapat diketahui bahwa kemampuan diversifikasi investasi bank konvensional lebih baik dibandingkan bank syariah.

Non-Performing Loan pada bank konvensional menghasilkan nilai rata-rata sebesar 0.035 dengan nilai standar deviasi sebesar 0.023. Sedangkan nilai NPL pada bank syariah menghasilkan nilai rata-rata sebesar 0.035 dengan nilai standar deviasi sebesar 0.018 . kondisi ini mengindikasikan bila nilai rata-rata NPL antara bank konvensional dan bank syariah cenderung sama.

Loan to Total Assets bank konvensional memiliki nilai rata-rata sebesar 0.604 dengan nilai standar deviasi sebesar 0.099. Sedangkan nilai Loan to Total Assets bank syariah menghasilkan nilai rata-rata sebesar 0.297 dengan nilai standar deviasi sebesar 
0.279. Berdasarkan hasil ini, dapat diketahui bahwa kemampuan bank syariah dalam mengelola likuiditas lebih baik dibandingkan bank konvensional.

Return on Assets bank konvensional memiliki nilai rata-rata sebesar 0.004 dengan nilai standar deviasi sebesar 0.020. Sedangkan ROA bank syariah memiliki rata-rata 0.271 dengan nilai standar deviasi sebesar 1.181. Berdasarkan hasil tersebut, dapat diketahui bahwa kemampuan bank konvensional untuk memperoleh laba menggunakan asetnya lebih baik daripada bank syariah.

Inflation rate menghasilkan nilai rata-rata sebesar 0.028 dengan nilai standar deviasi sebesar 0.006. Nilai maksimum inflation rate sebesar 0.036 pada tahun 2017 , sedangkan nilai minimum inflation rate sebesar 0.017 pada tahun 2020. Gross Domestic Product menghasilkan nilai rata-rata sebesar 0.036 dengan nilai standar deviasi sebesar 0.029. Nilai maksimum Gross Domestic Product pada tahun 2018 dengan nilai sebesar 0.052, sedangkan nilai minimum Gross Domestic Product pada tahun 2020 dengan nilai sebesar -0.021. berdasarkan data tersebut, pada tahun 2020 terjadi penurunan yang signifikan pada inflation rate dan GDP. Hal ini disebabkan terjadinya terjadi pandemi Covid-19 di tahun 2020 sehingga sektor ekonomi makro menjadi tertekan.

Bank size pada bank konvensional menghasilkan nilai rata-rata sebesar 17.401 dengan nilai standar deviasi sebesar 1.874. Sedangkan size bank syariah menghasilkan nilai rata-rata sebesar 16.102 dengan nilai standar deviasi sebesar 1.692. Berdasarkan data tersebut, dapat diketahui bank konvensional memiliki size yang lebih besar daripada bank syariah.

Interbank Ratio bank konvensional menghasilkan nilai rata-rata sebesar 0.882 dengan nilai standar deviasi sebesar 0.215 . IBR bank syariah menghasilkan nilai rata-rata sebesar 3.081 dengan nilai standar deviasi sebesar 5.384. Berdasarkan data tersebut, dapat diketahui bahwa kemampuan bank konvensional untuk mengelola likuiditas lebih baik dibandingkan dengan bank syariah. Rasio IBR bank konvensional lebih rendah, hal tersebut akan berpengaruh terhadap jumlah pendapatam kredit yang dihasilkan.

Capitalization Ratio menghasilkan nilai rata-rata sebesar 0.232 dengan nilai standar deviasi sebesar 0.145. Sedangkan CAP bank syariah menghasilkan nilai rata-rata sebesar 0.269 dengan nilai standar deviasi sebesar 0.109. Berdasarkan data tersebut, dapat diketahui antara bank konvensional dengan bank syariah memiliki nilai CAP yang relatif sama. Hal ini mengindikasikan bila kedua bank tersebut memiliki modal yang cukup untuk menunjang kegiatan operasional.

\section{DISKUSI}

Analisis Regresi Data Panel. Penelitian ini mengaplikasikan analisis regresi data panel untuk menguji pengaruh credit risk, liquidity risk, profitability, inflation rate, GDP bank size, interbank ratio, capitalization ratio terhadap investment diversification. Hasil persamaan regresi data panel dalam penelitian ini dapat dijabarkan sebagai berikut.

$$
\begin{aligned}
& \text { HHI }=2.243206-0.555799 \boldsymbol{N P L}-0.212956 \boldsymbol{L T} \boldsymbol{A}+1.679809 \mathrm{ROA}+ \\
& 2.567057 I N F+0.051149 G D P+0.096423 S I Z E-0.028518 I B R- \\
& 0.022095 \text { CAP. }
\end{aligned}
$$


Uji T. Tujuan dari uji $\mathrm{T}$ ialah untuk mengukur seberapa besar pengaruh variabel indenpenden terhadap pada variabel dependen. Kriteria pengujian dari Uji-Test yaitu jika signifikansi $\mathrm{t}<0.05$ maka $\mathrm{H}_{0}$ ditolak dan jika signifikansi $\mathrm{t}>0.05$ maka $\mathrm{H}_{0}$ diterima. Dari hasil pengujian maka didapatkan hasil seperti pada Tabel 8.

Tabel 6. Hasil Uji T

\begin{tabular}{c|c|c|c}
\hline \multirow{2}{*}{ Variabel Independen } & \multicolumn{3}{|c}{ Variabel Dependen } \\
\cline { 2 - 4 } & Koefisien & Probabilitas & Kesimpulan \\
\cline { 2 - 4 } & 2.2433206 & - & - \\
\hline Konstanta & -0.555799 & 0.0286 & Negatif Signifikan \\
\hline NPL & -0.212956 & 0.0313 & Positif Signifikan \\
\hline LTA & 1.679809 & 0.0134 & Positif Signifikan \\
\hline ROA & 2.567057 & 0.0351 & Positif Signifikan \\
\hline INF & 0.051149 & 0.0344 & Tidak Berpengaruh \\
\hline GDP & 0.096423 & 0.0475 & Tidak Berpengaruh \\
\hline SIZE & -0.028518 & 0.6777 &
\end{tabular}

Sumber: Output Panel Data RegresiEviews 12.0

Berdasarkan uji regresi data panel pada tabel 6, mengindikasikan bila NPL dan LTA berpengaruh negatif dan signifikan terhadap investment diversification pada perusahaan perbankan konvensional di Indonesia. Kondisi ini selaras dengan penelitian (Ammar dan Boughrara, 2019), (Nguyen, 2019) dan (Li dan Zhang, 2013), (Alandejani dan Asutay, 2017), (Marozva, 2020), (Karkowska, 2019), dan (Ammar et al., 2019). Semakin besar kredit macet (NPL) dalam suatu bank, maka bank akan menurunkan investasi. Ketika bank memiliki liquidity risk yang tinggi bank akan kekurangan dana untuk melunasi dana pihak ketiga. Akibatnya non-interest income bank akan menurun dan berpengaruh pada investment diversification.

Sedangkan ROA, INF, GDP, dan SIZE memiliki pengaruh positif terhadap investment diversivication. Hal ini sejalan dengan penelitian (Kipleting, 2016), (Hailu dan Tassew, 2018), (Alkhouri dan Arouri, 2021), (Ammar et al., 2019) dan (Gafrej dan Boujelbene, 2021). Profitabilitas yang tinggi mencerminkan semakin baik kinerja bank sehingga bank akan melakukan investasi ke berbagai instrumen investasi. Hal tersebut akan meningkatkan NONII dan HHI. Selain tingkat profitabilitas terdapat faktor macroeconomy yang mempengaruhi HHI, yaitu tingkat inflasi dan GDP. Semakin tinggi tingkat inflasi, maka bank cenderung menambah porsi investasinya. Sehingga mereka akan cenderung berinvestasi ke asset yang memiliki tingkat likuiditas yang baik. Menurut penelitian (Alkhouri dan Arouri, 2021) dan (Amidu dan Wolfe, 2013) menunjukkan bahwa faktor makroekonomi khususnya tingkat GDP berpengaruh negatif terhadap Herfindahl-Hirschmann Index (HHI). Berdasarkan penelitian (Nguyen, 2019) dan (Vallascas dan Keasey, 2012). Semakin besar ukuran simpanan bank (bank size), maka akan semakin tinggi saldo pinjaman bagi pelanggan. Selain itu, semakin besar size dari suatu industri perbankan, maka mereka akan melakukan investasi yang lebih berisiko. 
Uji regresi data panel penelitian ini menyatakan bila tidak terdapat pengaruh antara interbank ratio (IBR) dan capitalization ratio (CAP) terhadap investment diversification. IBR menunjukkan bahwa jatuh tempo deposito memiliki jangka waktu yang lebih cepat daripada jatuh tempo kredit yang diberikan. Biasanya deposito mempunyai jangka waktu di bawah satu tahun sedangkan kredit mempunyai jangka waktu lebih dari lima tahun. Semakin banyak nasabah yang melakukan deposito, maka bank akan memutar dana tersebut dengan menyalurkan kredit kepada nasabah. Dengan adanya rasio IBR, investor akan mengetahui kemampuan bank untuk memenuhi kebutuhan dana deposito dengan menggunakan kredit yang diberikan yang memiliki jangka waktu lebih lama daripada deposito. Dengan begitu, rasio ini tidak memiliki pengaruh terhadap investment diversification. Selain itu, rasio CAP juga tidak berpengaruh terhadap investment diversification. Hal ini dikarenakan mayoritas modal bank bersumber dari dana pihak ketiga berupa tabungan, giro dan deposito. Modal ini akan mempengaruhi asset yang dimiliki oleh bank. Dengan begitu CAP tidak berpengaruh terhadap investment diversification.

\section{KESIMPULAN}

Penelitian ini ditujukan untuk menganalisis pengaruh antara credit risk, liquidity risk, profitability, inflation rate, Gross Domestic Product, bank size, interbank ratio, dan capitalization ratio terhadap investment diversification pada perusahaan sektor perbankan yang terdaftar di Bursa Efek Indonesia (BEI) dengan sampel yakni 36 perbankan konvensional dan 4 perbankan syariah pada tahun 2018-2020. Berdasarkan hasil pengujian yang dilakukan, maka terdapat beberapa kesimpulan yaitu: (1) Credit risk berpengaruh negatif signifikan terhadap investment diversification. (2) Liquidity risk berpengaruh negatif signifikan terhadap investment diversification. (3) Profitability tidak berpengaruh terhadap investment diversification. (4) Inflation rate berpengaruh positif signifikan terhadap investment diversification. (5) Gross Domestic Product berpengaruh positif signifikan terhadap investment diversification. (6) Bank size berpengaruh positif signifikan terhadap investment diversification. (7) Interbank ratio tidak berpengaruh terhadap investment diversification. (8) Capitalization ratio tidak berpengaruh terhadap investment diversification. Berdasarkan hasil dari penelitian, kesimpulan, dan keterbatasan terhadap penelitian ini maka harapannya di masa mendatang akan ada penambahan jumlah sampel bank syariah agar dapat dilakukannya uji regresi data panel sehingga hasil penelitian lebih robust.

Saran. Mengacu pada kesimpulan dari hasil penelitian yang telah dilaksanakan, maka saran teruntuk peneliti selanjutnya ialah berikut ini. (1) Berdasarkan hasil proyeksi Bursa Efek Indonesia, terdapat pertumbuhan bank syariah yang melakukan listing untuk beberapa tahun ke depan. Maka dari itu, penelitian lanjutan harapannya mampu menggunakan bank syariah sebagai sampel penelitian. (2) Menambahkan variabel good corporate governance sesuai dengan penelitian (Gafrej dan Boujelbene, 2021) dan (Nguyen, 2019) karena membahas risiko dalam investasi perbankan konvensional dan syariah. 


\section{DAFTAR PUSTAKA}

Alandejani, M., Kutan, A. M., and Samargandi, N. (2017). Do Islamic Banks Fail More than Conventional Banks? Journal of International Financial Markets.

Alkhouri, R., and Arouri, H. (2021). The Effect of Diversification on Risk and Return in Banking Sector: Evidence from The Gulf Cooperation Council Countries. International Journal of Managerial Finance.

Amidu, M., and Wolfe, S. (2013). Does Bank Competition and Diversification Lead to Greater Stability? Evidence from Emerging Markets. Review of Development Finance, 152-166.

Ammar, and Boughrara. (2019). The Impact of Revenue Diversification on Bank Profitability and Risk: Evidence from MENA Banking Industry. Macroeconomics and Finance in Emerging Market Economies.

Avci, E., and Nassar, S. (2017). Intelectual Capital and Its Impact on Firm Performance of the Turkish Financial Sector Before and After Financial Crisis. Press Academia Procedia, 916.

Büyükşalvarci, A. (2012). Determinants of Capital Adequacy Ratio in Turkish Banks:. Journal of Business Management 5(27), 1119-11209.

Canh, N. P., Schinckus, C., Su, T. D., and Chong, F. H. (2021). Institutional Quality and Risk in The Banking System. Journal of Economics and Finance.

Chen, Y., Wei, X., Zhang, L., and Shi, Y. (2013). Sectoral Diversification and the Banks' Return and Risk: Evidence from Chinese Listed Commercial Banks. Procedia Computer Science Volume 18, 1737-1746.

Cihakl, M., and Hesse, H. (2011). Islamic Banks and Financial Stability: An Empirical Analysis. Journal of Financial Services Research.

Curi, C., Lozano-Vivas, A., and Zelenyuk, V. (2015). Foreign bank diversification and efficiency prior to and during the financial crisis: Does one business model fit all? Journal of Banking and Finance, S22-S35.

Gafrej, O., and Boujelbene, M. (2021). The Impact of Performance Liquidity and Credit Risks on Banking Diversification. International Journal of Islamic Banking.

Ghenimi, A., Chaibi, H., and Omri, M. A. (2017). The Effects of Liquidity Risk and Credit Risk on Bank Stability: Evidence from the MENA Region. Borsa Instanbul Review, 238-248.

Ghenimi, A., Chaibi, H., and Omri, M. A. (2020). Liquidity Risk Determinants: Islamic vs Conventional banks. International Journal of Law and Management.

Hacini, I., Boulenfad, A., Dahou, K. (2021). The Impact of Liquidity Risk Management on the Financial Performance of Saudi Arabian Banks. Emerging Market Journal, 73

Hailu, A. and Tassew, A. (2018). The impact of investment diversification on financial performance of commercial banks in Ethiopia. Financial studies. Bucharest Vol. 22.20

Hugonnier, J., and Morellec, E. (2017). Bank Capital, Liquid reserves, and insolvency risk. Journal of Financial Economics Vol 125, 266-285.18, 41-45

Jianu, I., Jianu, I., and Turlea, C. (2017). Measuring The Company's Real Performance by Physical Capital Maintenance. Economic Computation and Economic Cybernetics Studies and Research. 
Karkowska, R. (2019). Model of Risk Diversification in the Banking Sector. Folia Oeconomica Stetinensia, 31-42.

Khan, M., and Bhatti, I. (2008). Islamic Banking and Finance: On its Way to Globalization. Managerial Finance, 708-725.

Karkowska, R. (2013). Model of risk diversification in the banking sector. Folia Oeconomica Stetinensia, Vol. 19 No. 1, pp. 32-42.

Kipleting, M. (2016). Effect of investment diversification on the financial performance of commercial. IOSR Journal of Business and Management, Vol. 18 No. 11, 102115.

Koju, L., Koju, R., and Wang, S. (2018). Macroeconomic and Bank-Specific Determinants of Non-Performing Loans: Evidence from Nepalese Banking System. Journal of Central Banking Theory and Practice, 111-138.

Le, T. D., and Pham, X. T. (2021). The Inter-Relationships Among Liquidity Creation, Bank Capital and Credit Risk: Evidence from Emerging Asia-Pacific Economies. Managerial Finance.

Li, and Zhang. (2013). Are There Diversification Benefits of Increasing Noninterest Income in The Chinese Banking Industry? Journal of Empirical Finance.

Lopez, M., Tenjo, F., and Zarate, H. M. (2014). Credit Cycles, Credit Risk and Countercyclical Loan Provisions. Ensayos Sobre Politica Economica 32, 9-17.

Marozva, G. (2020). Liquidity Mismatch Index and Banks Stock Returns. International Journal of Economics and Business Administration.

Nguyen, N. (2019). Revenue Diversification, Risk and Bank Performance of Vietnamese Commercial Banks. Journal of Risk and Financial Management.

Paragina, A. B., and Muchtar, S. (2021). Factors Affecting Credit Risk of Conventional Banks Listed. Journal of Futures Studies.

Raei, R., Farhangzadeh, B., Safizadeh, M., and Raei, F. (2016). Study of the Relationship between Credit Diversification Strategy and Banks' Credit Risk and Return: Evidence from Tehran Stock Exchange (TSE). Procedia Economics and Finance, 62-69.

Rupeika-Apoga, R., Zaidi, S. H., and Thalassinos, Y. E. (2018). Bank Stability: The Case of Nordic and Non-Nordic Banks in Latvia. International Journal of Economics and Business Administration.

Saunders, A., Cornett, M. M., and McGraw, P. A. (2011). Financial institutions management: A risk management approach (Vol. 8). New York: McGrawHill/Irwin.

Uslu, H. (2020). Intellectual Capital in Islamic Banking Sector. Journal of Politics and Development, 51.

Vallascas, F., and Keasey, K. (2012). Bank resilience to systemic shocks and the stability of banking systems: Small is beautiful. Journal of International Money and Finance, 1745-1776.

Verma, R. K., and Bansal, R. (2021). Impact of Macroeconomic Variables on The Performance of Stock Exchange: a Systematic Review. International Journal of Emerging Markets.

Vidyarthi, H. (2020). Dynamics of Income Diversification and Bank Performance in India. Journal of Financial Economic Policy. 
Wang, R. and Luo, H.(R). (2020). Oil prices and bank credit risk in MENA countries after the 2008 financial crisis. International Journal of Islamic and Middle Eastern Finance and Management Vol. 13 No. 2, 219-247

$\mathrm{Yu}, \mathrm{H}$., and Kim, T. (2021). The Effects of Status on the Performance of Portfolio Diversification Strategies. Journal of Strategy and Management. 